\title{
PENGEMBANGAN BUSANA PESTA MALAM DENGAN SUMBER IDE DARI MITOLOGI KERAJAAN YUNANI
}

\author{
Agustini, I Gede Sudirtha, Made Diah Angendari \\ Jurusan Pendidikan Kesejahteraan Keluarga \\ Universitas Pendidikan Ganesha \\ Singaraja, Indonesia
}

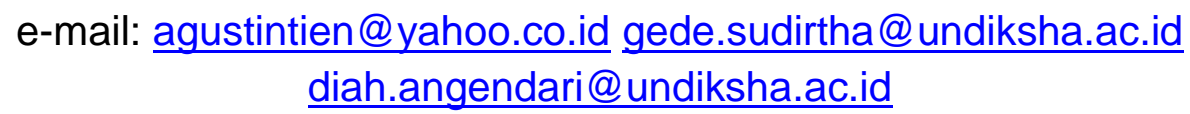

\begin{abstract}
Abstrak
Penelitian ini bertujuan untuk mengetahui proses dan hasil pengembangan busana pesta malam dengan sumber ide dari mitologi kerajaan Yunani. Penelitian ini merupakan penelitian pengembangan (Research and Development), menggunakan metode pengembangan Borg \& Gall. Proses penelitian pengembangan busana pesta malam ini dilakukan melalui beberapa tahap, yaitu tahap pengumpulan data, perencanaan, pengembangan, validasi dan uji coba busana pesta malam. Pengumpulan data yang digunakan dalam penelitian ini dengan menggunakan metode kuesioner/angket. Hasil pengembangan busana pesta malam dengan sumber ide dari mitologi kerajaan Yunani terdiri dari dua busana yaitu busana pesta malam I busana yang bersumber ide dari busana perang Dewi Athena terlihat pada bagian draperi selendang. Sedangkan busana pesta malam II busana bersumber ide dari Dewi Athena terlihat pada hiasan dibagian dada, warna busana pesta, dan aksesoris. Untuk uji ahli produk dengan hasil penilaian $89,41 \%$ yang termasuk dalam kualifikasi produk pengembangan busana pesta malam dengan sumber ide dari mitologi kerajaan Yunani dikatagorikan baik.
\end{abstract}

Kata kunci : Busana pesta malam, Mitologi Kerajaan Yunani, Pengembangan, Sumber Ide.

\footnotetext{
Abstrack

This study aims to determine the process and results of the development of evening party dress with a source of ideas from Greek royal mythology. This research is a development research (Research and Development), this study using Borg \& Gall's development method. The research process for evening party fashion development was carried out through several stages, namely the stage of data collection, planning, development, validation and testing of evening party attire. Collecting data used in this study using questionnaire / questionnaire method. The results of the development of evening party dress with a source of ideas from Greek royal mythology consisted of two outfits, namely the evening party dress I, clothing that originated from the ideas of the warrior goddess Athena seen in draperi scarves. While the evening party dress II, fashion originating from the idea of the Goddess Athena, is seen on the chest decoration, party dress colors, and accessories. For expert test products with $89.41 \%$ assessment results included in the qualification of night party fashion development products with a source of ideas from Greek mythology are categorized as good.
} 
Keywords: Evening party dress, Greek Kingdom Mythology, Development, Idea Source.

\section{PENDAHULUAN}

Busana merupakan kebutuhan pokok manusia. Menurut Soekarno (2002:1), busana mempunyai hubungan yang erat dengan manusia karena menjadi salah satu kebutuhan utamanya. Busana yang ada di masyarakat sekarang ini pada prinsipnya merupakan pengembangan dari bentuk dasar busana pada peradaban Barat. Sebenarnya asal mula busana Barat pun ada sumbangan yang tumbuh dari tiga akar budaya tercakup busana-nya, yaitu dari Yunani kuno, Romawi, dan dunia Nasrani.

Yunani Kuno adalah negara yang sangat berpengaruh pada peradaban dunia barat. Perkembangan mode busana sangat dipengaruhi oleh Yunani karena disanalah asal mula dari busana. Masyarakat Yunani Kuno memakai baju yang terbuat dari kain persegi yang diberi ikatan di bagian pinggang lalu dibiarkan dibiarkan jatuh dan terurai sesuai lekuk badan. Laki laki memakai baju yang menutupi hingga lutut. Sedangkan perempuan menutupi hingga pergelangan kaki. Baju ini juga disebut dengan Kiton. Orang Athena memakai Kiton ala Ionia. Kiton ala Lonia terbuat dari Ama, sangat tipis dan lembut. Keistimewaan kedua jenis Kiton itu juga sama dengan bentuk bangunan yang ada di kota. Bangunan ala Lonia di Athena terlihat mewah, megah, dan feminin.

Ibu kota Yunani yaitu Athena merupakan salah satu kota tertua di benua Eropa. Dengan kurang lebih selama 7.000 tahun sudah Yunani berpenduduk, menjadikan Yunani menjadi tempat lahirnya demokrasi, ilmu politik, olimpiade, prinsip matematika utama, komedi, filsafat barat, dan teori barat tentang tragedi.

Kemajuan peradaban Yunani yang paling menonjol adalah dari segi limu pengetahuan, salah satunya yaitu di bidang filsafat yang melahirkan banyak filsuf-filsuf hebat yang pemikiranaya masih dipakai sampai saat ini, antara lain Aristoteles, Plato, dan Socrates. Peradaban ini tidak hanya terkenal dengan pemikiran-pemikiran ilmuwanilmuwan yang masih dipakai sampai saat ini. Peradaban Yunani dalam kepercayaanya menganut Polyteisme yang mempercayai banyak Dewa, Dewa tertingginya adalah Dewa Zeus, yang oleh masyarakat Yunani dibuat kuil Dewa Zeus di gunung Olimpus untuk pemujaan kepadanya. Peradaban Yunani dapat dikatakan peradaban kuno yang sangat maju, jauh meninggalkan bangsa lain yang semasa dengannya. Mitologi

Yunani adalah sekumpulan mitos dan legenda yang berasal dari Yunani Kuno dan berisi kisah-kisah mengenai Dewa dan pahlawan, sifa dunia, dan asal usul serta makna dari praktik ritual dan agama orang Yunani Kuno. Sejak peradaban awal sampai berbentuk kerajaan, masyarakat Yunani mempercayai mitologi banyak Dewa yang dikembangkan pada peiode Mycenas yang digambarkan berupa kekuatan utama dalam kehidupan masyarakat Yunani. Dewa-Dewi ini digambarkan seperti manusia,tetapi memiliki kekuatan dan keindahan yang lebih di bandingkan dengan manusia dan hidup abadi. Dewa-Dewi ini tinggal di gunung Olympus dengan Dewa tertinggi Dewa Zeus. Karena merupakan Dewa tertinggi maka sebagai bentuk penghormatan kepada Dewa Zeus, dibuatkanlah kuil Dewa Zeus di gunung Olympus. Salah satu Dewi Yunani yang paling terkenal adalah Dewi Athena yang merupakan salah satu Anak dari Dewa Zeus. Dia adalah Dewi kebijaksanaan, perang, keindahan jiwa, seni, pendidikan, dan pengatur para Dewa di Olympus. Diantara semua patung DewaDewi Yunani yang ditempatkan di dalam kuil, yang paling terkenal adalah Parthenon. Kuil ini ada di Athena dibangun untuk Dewi Athena, pelindung kota.

Sebagai Dewi perang, simbol Athena antara lain baju perang, tombak, helm perang, perisai dengan kepala Gorgon, dan Aigis. Aigis adalah mantel 
atau jubah yang dihiasi dengan kepala Medusa dan dipercaya mampu memberikan perlindungan yang kuat (Aigis juga disebut sebagai perisai Zeus dan Athena dalam Vassilika 1998:20). Sementara Hewan yang merupakan atribut Athena adalah burung hantu, ular, dan laba-laba. Pohon yang dikeramatkan untuknya adalah pohon zaitun. Kuil tempat penyembahan Dewi Athena adalah kuil Parthenon yang merupakan salah satu monumen terbesar di Dunia. Athena juga kadang-kadang disertai Nike, Dewi kemenangan. Pada masa klasik, Athena digambarkan mengenakan chiton (pakaian orang Yunani kuno), kadang dengan ular di pinggangnya dan kadang mengenakan baju perang dengan helm agak terangkat ke atas. Athena juga sering digambarkan dengan burung hantu di salah satu pundaknya atau disertai seekor ular.

Sejak zaman dahulu dalam kehidupan sehari-hari manusia tidak bisa dipisahkan dari pemakaian busana. Dimasa kini, pakaian tidak lagi sebagai penutup tubuh melainkan dibuat desain menarik mempunyai daya cipta rasa, karsa dan karya. Seiring dengan perkembangan Ilmu Pengetahuan dan Teknologi, kegiatan dan aktifitas seseorang semakin banyak, sehingga dibutuhkan berbagai jenis busana yang dapat dipakai sesuai dengan kegiatan/kesempatan. Busana yang pantas dipakai dan sesuai dengan kesempatan, akan memudahkan seseorang dalam pergaulan sehari-hari. Pada umumnya setiap orang memerlukan busana untuk berbagai macam kesempatan antara lain, (busana rumah, busana kerja, busana olah raga, busana rekreasi, busana pesta, busana berkabung).

Salah satu busana yang memiliki keistimewaan tersendiri dibandingkan dengan busana-busana lainnya adalah busana pesta. Menurut Chodiyah dan Wisri A. Mamdy (1982) pengertian busana pesta adalah busana yang dikenakan pada kesempatan pesta, biasanya menggunakan bahan yang berkualitas tinggi dengan hiasan dan perlengkapan yang bagus dan lengkap sehingga kelihatan istimewa. Keistimewaan dari busana pesta tersebut adalah selalu dibuat istimewa, baik dari segi desain yang dirancang khusus, bahan dengan kualitas bagus, warna menarik dan mencolok, menggunakan teknik jahit yang halus, serta aksesoris yang indah dan menawan untuk melengkapinya. Busana pesta dikelompokan menjadi 5 busana yaitu: busana pesta pagi, busana pesta sore, busana pesta malam, busana pesta malam resmi, dan busana pesta malam gala.

Busana pesta malam gala adalah busana pesta yang dipakai pada malam hari untuk kesempatan pesta, dengan ciriciri mode terbuka, elegan, mewah. Agar busana pesta malam gala tidak terkesan biasa-biasa saja meskipun cara pembuatannnya yang istimewa perlu adanya inovasi baru dari seorang desainer dalam menciptakan desain busana. Desain yang dibuat harus sesuai dengan kondisi masyarakat saat ini, dimana konteks perkembangan ilmu pengetahuan dan teknologi yang melatar belakangi pertumbuhan sosialnya sangat erat dengan perubahan terhadap kondisi masyarakat serta sesuai dengan kegunaan dan kegiatan yang sesuai dengan busana pesta malam gala khususnya yang unik, praktis, namun masih terkesan elegan dan istimewa. Maka perlu bagi desainer untuk membuat inovasi baru tentang sebuah busana pesta yang lebih sesuai dengan kondisi masyarakat modern.

Dalam menciptakan suatu desain busana pesta, penuangan ide kreatif sangat diperlukan untuk menciptakan suatu desain busana. Ide dapat diambil dari berbagai hal. Misalnya pada perkembangan mode busana pada masa lampau, masa-masa Kerajaan, peristiwa yang telah terjadi, dari bentuk-bentuk alam sekitar, dapat pula dari perkembangan mode yang sudah ada kemudian dikembangkan lagi. Sumber ide yang telah ada kemudian dituangkan dalam sebuah desain busana. Menurut Sri Widarwati (1996:58) Sumber ide adalah segala sesuatu yang dapat menimbulkan seseorang untuk menciptakan suatu ide baru. Proses pembuatan desain busana 
yang selalu berkembang memerlukan sumber-sumber ide sebagai sumber inspirasi dalam meningkatkan kreativitas pembuatan desain busana.

Pemilihan sumber ide sangat penting dalam membuat suatu karya. menciptakan sebuah desain busana pesta malam diperlukan sebuah sumber ide. Pada penelitian ini penulis ingin mengembangkan pembuatan busana pesta malam yang dikembangkan dengan sumber ide dari Mitologi Kerajaan Yunani yaitu busana Dewi Athena. Karena dalam mitologi Yunani terdapat Dewa-Dewi Yunani yang sering dijadikan sumber ide dalam pembuatan suatu karya seni. Kemudian mengubah busana perang Dewi Athena menjadi busana pesta malam gala yang terkesan feminim dan elegan.

Pada proses pengembangan busana pesta malam bersumber Ide dari Mitologi Yunani khususnya mengembangkan busana perang Dewi Athena menjadi busana yang lebih praktis, anggun dan terkesan feminim tanpa melepaskan ciri khas dari busana Dewi Athena yang sebelumnya. Menciptakan busana pesta malam gala dipadukan dengan berbagai macam kain yang terkesan mewah dan dilengkapi dengan hiasan teknik sulam aplikasi, payet, permata, dan penambahan aksesoris yang dibuat untuk menggantikan busana perang Dewi Athena agar terkesan sebagai karya busana pesta malam gala yang memberi ciri khas tersendiri dari busana pesta lainnya.

Perlu ada inovasi dari desainer busana yang selalu mengerti kebutuhan masyarakat dan pasar, khususnya busana pesta malam gala. Sebagai realisasi kepentingan tersebut, diciptakanlah busana pesta malam yang diorientasikan untuk kepentingan menghadiri perayaan pesta malam gala. Diharapkan pengembangan busana pesta yang akan di ciptakan nantinya mampu memberi nuansa baru pada dunia fashion yang telah ada, dan menjadi gaya fashion baru.

\section{METODE PENELITIAN}

Penelitian dan pengembangan atau Research and Development (R\&D) atau sering disebut "pengembangan" adalah strategi atau metode penelitian yang cukup ampuh untuk memperbaiki praktik pembelajaran. Yang dimaksud dengan penelitian dan pengembangan adalah rangkaian proses atau langkahlangkah dalam rangka mengembangkan suatu produk baru dan memperbaiki produk-produk yang telah ada agar dapat dipertanggungjawabkan. Dapat disimpulkan bahwa tujuan utama dari penelitian perkembangan tersebut adalah bagaimana mendesain dan memproduksi suatu spesifikasi media atau produk yang ingin dikembangkan.

Pada penelitian ini peneliti menggunakan penelitian pengembangan yang berupaya untuk menghasilkan suatu produk busana pesta. Model pengembangan yang digunakan dalam penelitian ini adalah model Brog \& Gall. Pemilihan model penelitian pengembangan ini didasarkan pada pertimbangan bahwa model Borg \& Gall cocok untuk pengembangan sebuah produk busana dan dan langkah-langkah pengembangan ini bisa bermanfaat bagi pembaca.

Prosedur penelitian yang digunakan peneliti dalam pengembangan ini diadaptasi dari langkah-langkah pengembangan yang dikembangkan oleh Borg dan Gall, penerapannya disesuaikan dengan kebutuhan peneliti. Mengingat keterbatasan waktu, biaya yang dimiliki peneliti, dan juga penelitian pengembangan ini hanya bertujuan untuk memenuhi tugas akhir atau skripsi secara garis besar langkah-langkah penelitian dan pengembangan yang telah dikemukakan sebelumnya, disederhanakan sesuai kebutuhan penelitian. Hal tersebut didasari oleh Borg dan Gall (1981) dalam Emzir (2011:271) yang menyarankan dalam penelitian tesis dan disertasi penelitian dibatasi dalam skala kecil, termasuk dimungkinkan membatasi langkah penelitian.

Prosedur penelitian pengembangan busana pesta malam ini dibagi menjadi 4 bagian, yaitu: 1) pengumpulan data, 2) perencanaan, 3) pengembangan produk, 4) Validasi dan uji coba. Mengambil langkah utama Borg and Gall sampai 
pada tahap keempat, prosedur pengembangan busana pesta malam meliputi:

Pada tahap penelitian dan pengumpulan data pada pengembangan produk busana ini, peneliti mengumpulkan data untuk sumber ide yang akan dituangkan ke dalam desain busana. Sumber ide tersebut diambil pada sejarah kerajaan Yunani dan mitologi Yunani kuno. Mencari data terkait mitologi kerajaan Yunani dari buku. Pengumpulan data ini digunakan untuk memecahkan masalah yang dihadapi peneliti tentang sumber ide dalam merancang/mendesain suatu produk busana pesat malam. Sumber ide yang telah diambil pada mitologi Yunani adalah segala sesuatu yang terkait dengan Dewi Athena, baik itu dari segi busana, tempat penyembahan, maupun sesuatu yang identik dengan Dewi Athena. Jadi sumber ide yang diambil adalah busana Dewi Athena, kuil Parthenon, dan pohon Zaitun.

Selanjutnya peneliti membuat suatu desain busana sesuai dengan sumber ide yang sudah ditetapkan. Desain ini dibuat untuk menujukan sisi kefeminiman dan keanggunan Dewi Athena dalam desain busana dan juga dipadukan dengan sumber ide dari kuil parthenon, dalam kuil ini peneliti mengambil bentuk tiang kuil parthenon sebagai bentuk siluet busana dan warna bahan busana diambil dari kuil parthenon saat menjelang malam yang disinari cahaya membuat warnanya terlihat coklat muda dan berkilau.

Peneliti membuat beberapa desain sketsa, kemudian dari desain tersebut dipilih dua desain yang sesuai untuk dijadikan sebagai busana pesta malam gala. Setelah dua desain sketsa yang dipilih, kemudian membuat desain produksi dan analisis desain.

Tahap pengembangan dilakukan dengan mengrmbangkan sumber ide yang diambil untuk dijadikan sebagai sebuah produk. Dalam penelitian pengembangan ini akan menghasilkan dua produk busana dengan mengambil sumber ide dari mitologi Kerajaan Yunani. Beberapa ide yang diambil yaitu busana perang Dewi Athena, kuil tempat penyembahan Dewi
Athena, dan juga pohon zaitun. Selanjutnya dimulai dengan pengumpulan bahan, pengelolaan bahan, dan terakhir adalah produksi. Bahan-bahan yang dikumpulkan berupa kain untuk bahan utama, kain untuk bahan furing/linning, benang, dan alat-alat jahit. Setelah alat dan bahan terkumpul, dilakukan pengelolaan bahan oleh peneliti, yaitu dengan membuat suatu prodak busana pesta yang sesuai dengan sumber ide dan teknik jahit yang digunakan dalam membuat busana.

Produk busana yang telah diproduksi, kemudian dievaluasi. Bentuk dari evaluasi produk busana pesta malam ini adalah validasi produk oleh dua ahli busana yaitu seorang guru SMK dan seorang ahli praktisi busana yang memiliki sebuah industri di singaraja. Melalui tahap ini diperoleh data kelayakan produk dan saran dari ahli. Kemudian untuk uji coba produk dilakukan oleh model/praga.

Dalam penelitian ini, analisis deskriptif kuantitatif digunakan untuk mengolah data yang diperoleh melalui angket dalam bentuk skor. Rumus yang digunakan untuk menghitung menurut Tegeh dan Kirna (2010:101) dari masingmasung subjek sebagai berikut.

Persentase $=\frac{\text { Skor perolehan }}{\text { Skor maksimal }} \times 100 \%$

Selanjutnya, untuk menghitung presentase keseluruhan subjek digunakan rumus sebagai berikut.

Tabel 1. Konvensi Tingkat Pencapaian Skala 5.

\begin{tabular}{ll}
\hline $\begin{array}{c}\text { Tingkat } \\
\text { pencapaian }\end{array}$ & Kualifikasi \\
\hline $90 \%-100 \%$ & Sangat Baik \\
$75 \%-89 \%$ & Baik \\
$65 \%-74 \%$ & Cukup \\
$55 \%-64 \%$ & Kurang \\
$0-54 \%$ & Sangat Kurang \\
\hline
\end{tabular}


Produk yang akan di uji cobakan adalah hasil busana pesta malam gala mulai dari evaluasi hasil rancangan dan evaluasi hasil penerapan pengembangan. Evaluasi akan dilakukan oleh ahli (Expert Judgement) yang bertugas mengevaluasi instrument sebelum disebar kepada uji produk. Penelitian ini menggunakan analisis Gregori dimana menggunakan 2 orang ahli. Tingkat validasi pengembangan busana pesta malam gala ini akan dilakukan dalam 2 (dua) tahap yaitu. (1) Evaluasi yang akan dilakukan oleh ahli instrumen adalah mengevaluasi instrumen sebelum disebarkan kebada ahli produk untuk menguji produk, pada tahap ini evaluasi akan dilakukan oleh ahli busana yaitu dosen jurusan pendidikan kesejahteraan keluarga program studi tata busana. (2) Uji produk pada tingkat validasi pengembangan busana pesta malam gala ini dilakukan oleh seorang ahli yang berasal dari praktisi busana yang memiliki sebuah industri di Singaraja.

Subjek uji coba produk hasil pengembangan busana pesta malam gala ini menggunakan Uji Ahli (Expert Judjement) dimana ahli yang digunakan adalah ahli yang sudah berpengalaman di bidang busana. Uji ahli produk pada tahap ini dilakukan oleh guru SMKN 2 Singaraja dan owner butik Ria yang bertempat di Singaraja

Data yang diperoleh dalam proses pengembangan busana pesta malam ini berupa data kualitatif dan data kuantitatif. Analisis deskriptif kuantitatif digunakan untuk mengolah data yang diperoleh melalui angket dalam bentuk skor. Analisis deskriptif kualitatif merupakan suatu teknik yang menggambarkan dan menginterprestasikan arti data-data yang telah terkumpul dengan memberikan perhatian dan merekam sebanyak mungkin aspek situasi yang diteliti pada saat itu sehingga memperoleh gambaran secara umum dan menyeluruh tentang keadaan sebenarnya.

Kuesioner atau angket merupakan suatu teknik atau cara pengumpulan data secara tidak langsung (peneliti tidak langsung bertanya-jawab dengan responden). Kuesioner digunakan untuk mengumpulkan review ahli busana, ahli desain, dan mahasiswa saat uji coba perorangan. Kuesioner ini digunakan sebagai instrument untuk memvalidasi pengembangan busana pesta malam gala.

Analisis data dilakukan untuk memperoleh pemahaman yang kongkret tentang keberhasilan pengembangan busana yang sudah diproduksi. Hasil yang diperoleh digunakan sebagai bahan pertimbangan dalam memperbaiki hasil produksi. Teknik analisa data yang diguakan pada tahap ini yaitu.

Dalam penelitian ini, analisis deskriptif kuantitatif digunakan untuk mengolah data yang diperoleh melalui angket dalam bentuk skor. Pada tahap ini untuk mengetahui kriteria kevalidan instrumen pengembangan. Analisis deskriptif kualitatif merupakan suatu teknik yang menggambarkan dan menginterprestasikan arti data-data yang telah terkumpul dengan memberikan perhatian dan merekam sebanyak mungkin aspek situasi yang diteliti pada saat itu sehingga memperoleh gambaran secara umum dan menyeluruh tentang keadaan sebenarnya.

\section{HASIL DAN PEMBAHASAN Hasil Penelitian}

\section{Proses Pengembangan Busana Pesta Malam dengan Sumber Ide dari Mitologi Kerajaan Yunani}

Dalam pengmbangan busana pesta malam ini memerlukan suatu tahapan-tahapan agar proses pengmbangan produk busana berjalan dengan baik. Berdasarkan langkah dalam penelitian pengembangan Borg \& Gall yang disederhanakan menjadi 4 tahap maka didapatkan proses penembangan busana pesta malam sebagai berikut :

\section{Tahap pengumpulan data}

Pada tahap penelitian dan pengumpulan data pada pengembangan produk busana ini, peneliti mengumpulkan data untuk sumber ide yang akan dituangkan ke dalam desain busana. Sumber ide tersebut diambil pada sejarah kerajaan Yunani dan mitologi Yunani kuno. Mencari data terkait mitologi kerajaan Yunani dari buku. Pengumpulan data ini digunakan untuk memecahkan 
masalah yang dihadapi peneliti tentang sumber ide dalam merancang/mendesain suatu produk busana pesta malam. Sumber ide yang telah diambil pada mitologi Yunani adalah Dewi Athena dan hal-hal yang berkaitan dengan Dewi Athena, yaitu Busana perang Dewi Athena, kuil Parthenon, dan pohon zaitun.

Menganalisis busana perang Dewi Athena, busana perang yang identik dengan keberanian, kuat, dan hebat. Mengubah busana perang Athena menjadi busana yang cocok dipakai pada pesta malam gala. peneliti ingin menujukan sisi kefeminiman dan keanggunan Dewi Athena tetapi masih memiliki kesan kuat di dalam desain busana.Mengembangkan busana perang Dewi Athena menjadi busana yang lebih praktis, elegan dan terkesan feminim tanpa melepaskan ciri khas dari busana Dewi Athena yang sebelumnya. Peneliti juga mengambil siluet dan warna busana dari kuil Parthenon untuk di jadikan desain busana pesta malam gala. kemudian menambahkan warna emas tembaga untuk memberikan kesan kuat dan mewah.

Yunani adalah produsen Zaitun terbesar ketiga setelah Spanyol dan Italia. Yunani memproduksi 2.232.412 metrik ton zaitun per tahun. Sekitar $60 \%$ dari lahan budidaya di Yunani digunakan untuk produksi zaitun. Buah zaitun memiliki banyak kegunaan seperti menjadi bahan makanan dan obat. Daun zaitun sering dijadikan sebagai sumber ide untuk pembuatan mahkota pada zaman Yunani Kuno. Sehingga peneliti tertarik untuk menjadikan daun zaitun sebagai hiasan busana dan aksesoris busana pesta. Kemudian juga menambahkan hiasan aplikasi dari brokat dan tambahan payet serta mote warna emas tembaga untuk memberikan kesan elegan dan terlihat klasik untuk menggantikan senjata yang di bawa Athena agar desain tersebut cocok untuk busana pesta malam gala. Peneliti ingin mengembangkan busana perang Dewi Athena menjadi busana pesta malam gala. selain busana perang Athena, peneliti juga mengambil sumber ide dari kuil yang dibuat untuk Dewi Athena yaitu kuil Parthenon, dan pohon zaitun yang merupakan pohon yang ditanam Dewi Athena saat memperebutkan kota Athena.

Selain pengumpulan data tentang sumber ide, peneliti juga mengumpulkan data tentang teori desain, busana, busana pesta malam, dan pembuatan pola. Teoriteori ini didapatkan dari buku dan sumber lainnya.

\section{Tahap Perencanaan}

Tahap perencanaan dimulai dengan menentukan sumber ide apa saja yang akan diambil untuk pembuatan produk busana ini. Pada penentuan sumber ide ini peneliti telah menentukan akan mengambil mitologi Kerajaan Yunani khususnya tentang Dewi Athena sebagai sumber ide untuk desain produk busana pesta malam. Selanjutnya peneliti membuat suatu desain sketsa busana sesuai dengan sumber ide yang sudah ditetapkan. Desain ini dibuat untuk menujukan sisi kefeminiman dan keanggunan Dewi Athena dan kepraktisan dari busana pesta yang telah dikembangkan. Dan juga dipadukan dengan sumber ide dari kuil parthenon, dan daun zaitun. Setelah membuat enam desain sketsa, kemudian memilih dua desain yang akan dijadikan desain busana dan analisis desain.

\section{Tahap Pengembangan produk}

Pengembangan adalah proses mewujudkan desain yang dibuat tadi menjadi kenyataan. Desain busana pesta malam yang menggambarkan busana perang Dewi athena yang dikembangkan menjadi busana pesta malam gala yang lebih feminim dan seksi namun terkesan mewah ini dikembangkan sesuai dengan langkah-langkah pengembangan yang sudah direncanakan. Pengembangan bentuk busana perang Dewi athena yang dikombinasikan dengan pengambilan siluet busana dari tiang kuil parthenon untuk mengubah siluet dari busana perang sebelumnya agar lebih simple dan praktis. Kemudian mengubah prisai Aigis pada bagian dada menjadi sulam aplikasi bordir brokat yang ditaburkan payet dan mote agar busana tersebut sesuai denga kesempatan busana pesta malam gala. menambahkan warna busana seperti 
warna kuil, warna emas tembaga untuk memberi kesan kuat sebagai pengganti atribut busana perang Athena.

Bahan busana yang digunakan adalah satin gliter sebagai bahan utama, kain tile, dan kain hero untuk bagian furing. Sedangkan untuk menghias busana digunakan brokat timbul untuk membuat sulaman Aplikasi, payet, mote, permata, kawat dan matras yang sudah dilengkapi gliter untuk membuat aksesoris. Dan bahan pelengkap untuk pembuatan busana seperti benang, bisban, filsofik, dan lain-lain.dan juga ada tahap ini meiputi prosese pembuatan busana pesta malam mulai dari pembuatan pola, menjahit busana, teknik penyelesaian, dan pembuatan aksesoris busana pesa malam.

\section{Tahap Validasi dan Uji Coba Produk}

Produk busana yang telah diproduksi, kemudian dievaluasi. Bentuk dari evaluasi produk busana pesta malam ini adalah validasi. Validasi produk oleh dua ahli busana yaitu seorang guru SMK dan seorang ahli praktisi busana yang memiliki sebuah industri di singaraja. Melalui tahap ini diperoleh data kelayakan produk dan saran dari ahli. Sedangkan untuk uji coba produk dilakukan oleh model/praga. Paparan untuk mengetahui hasil pengujian yang dimaksud adalah sebagai berikut.

Penilaian ahli produk Untuk memperoleh informasi kualifikasi produk pengembangan busana pesta malam dengan sumber ide dari mitologi kerajaan Yunani, peneliti memberikan kuesioner berupa lembar instrument yang terdiri dari 4 indikator dan 17 butir pernyataan dengan hasil penilaian. Berdasarkan data yang diperoleh dari hasil validitas uji produk pengembangan busana pesta malam dengan sumber ide dari mitologi kerajaan Yunani yang terdiri dari 2 validator selanjutnya dianalisis menggunakan rumus Tegeh dkk (2014) sebagai berikut

Tabel 2. Hasil Validitas Uji Produk

Penilai Hasil \%

\begin{tabular}{lc}
\hline Ahli I & $91,77 \%$ \\
Ahli II & $87,06 \%$ \\
Total Nilai & $89,41 \%$ \\
\hline
\end{tabular}

Jadi tingkat pencapaian validitas produk adalah $89,41 \%$ dengan penghitungan tersebut, maka kualifikasi produk dapat dikatagorikan Baik.

\section{Hasil Pengembangan Busana Pesta Malam dengan Sumber Ide dari Mitologi Kerajaan Yunani}

Berdasarkan dengan proses pengembangan busana pesta malam dengan sumber ide dari mitologi Kerajaan Yunani. mengambil hal-hal yang terkait dengan Dewi Athena diambil sebagai sumber ide, seperti busana perang Dewi Athena, kuil Parthenon yang dibuat untuk tempat penyembahan Dewi Athena, kemudian pohon zaitun karena pada saat memperebutkan kota Athena Dewi Athena menanam pohon zaitun untuk rakyat, maka dapat terlihat hasil pengembangan busana pesta malam terdiri dari dua busana pesta malam yaitu busana pesta malam I dan busana pesta malam II sebagai berikut.

\section{Busana Pesta Malam I}

Hasil pengembangan busana pesta malam I dengan sumber ide dari mitologi Kerajaan Yunani khususnya diambil dari busana Dewi Athena dengan mengembangkan busana perang busana Dewi Athena sesuai dengan karakteristik busana pesta malam. Menambahkan teknik draperi pada selendang bagian dada kiri. Busana dengan bagian atas yang bebentuk kamisol dan terdapat belahan pada sisi paha kanan agar busana tersebut terkesan seksi dan feminim. Bahan busana menggunakan bahan satin gliter warna coklat muda sesuai dengan warna kuil Parthenon, kemudian menambahkan hiasan aplikasi menggunakan brokat timbul yang ditaburi payet pada bagian bawah gaun agar busana tersebut lebih istimewa. Untuk aksesoris dibuat dari matras yang sudah ditaburi gliter warna emas berbentuk daun 
Jurnal Bosaparis: Pendidikan Kesejahteraan Keluarga

Volume 9, Nomor 3, November 2018

zaitun untuk membuat mahkota sebagai pengganti helm perang Dewi Athena. payet dan permata pada bagian bawah lengan. Menggunakan bahan yang sama dengan busana pesta malam I.

\section{Gambar 1. Hasil Akhir Busana Pesta Malam I}
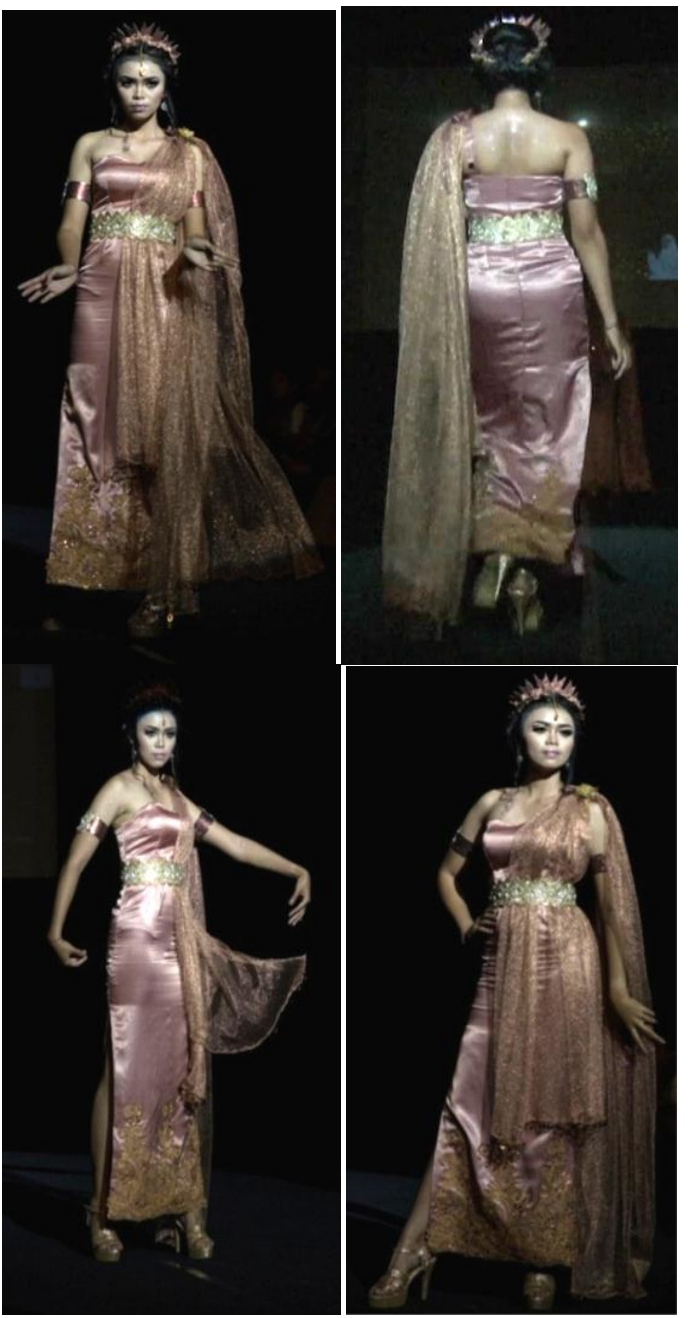

\section{Busana Pesta Malam II}

Hasil pengembangan busana pesta malam II dengan sumber ide dari prisai baju perang Dewi Athena yaitu Aigis. Mengubah perosai tersebut menjadi hiasan aplikasi menggunakan brokat timbul warna emas tembaga yang di taburi dengan payet, mote, dan permata agar busana tersebut sesuai dengan karakteristik busana pesta malam. Menggunakan variasi lengan yang lebih menyerupai jubah dan menambah hiasan

\section{Gambar 2. Hasil Akhir Busana Pesta Malam II}

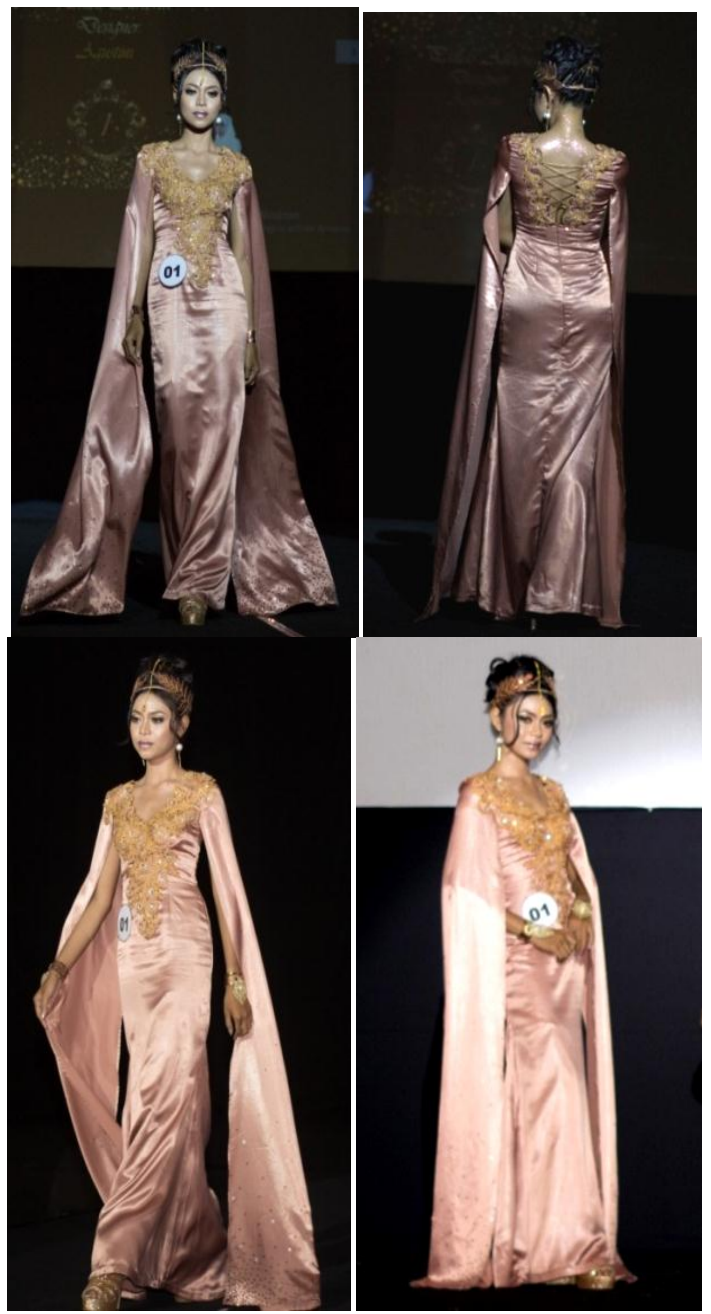

\section{Pembahasan}

Berdasarkan Hasil Penelitian sesuai dengan rumusan masalah, yaitu: 1) Bagaimana proses pengembangan busana pesta malam dengan sumber ide dari Kerajaan Yunani ? 2) Bagaimana hasil pengembangan busana pesta malam dengan sumber ide dari Kerajaan Yunani ? Maka dapat dipaparkan sebagai berikut.

\section{Proses Pengembangan Busana Pesta Malam}


Dalam proses pengembangan busana pesta malam dengan sumber ide mitologi Kerajaan Yunani ini menggunakan model pengembangan Borg \& Gall. Model Borg \& Gall menggunakan 10 tahap pengembangan, tapi di dalam penelitian ini menggunakan 4 tahap pengembangan yaitu, tahap pengumpulan data, tahap perencanaan, tahap pengembangan produk, dan tahap validasi dan uji coba. Dalam penelitian ini menggunakan 4 tahap pengembangan yang diadaptasi dari kajian yang relevan yang dilakukan oleh Eri Isnani pada tahun 2014 dalam jurnal UNY, Fakultas IImu Sosial, Pendidikan IPS, yang berjudul "Pengembangan Sumber Belajar IPS Bentuk Majalah Dengan Materi Interaksi Manusia dan Lingkungan Untuk Siswa Kelas VII SMP" Penelitian ini merupakan penelitian pengembangan (Research and Development). Penelitian pengembangan ini menggunakan model Brog \& Gall. Tetapi untuk menghemat waktu, dan biaya, penelitian pengembangan ini dilakukan hanya melalui beberapa tahap, yaitu tahap pengumpulan data, perencanaan, pengembangan, validasi, dan uji coba. Dikarenakan peneliti juga ingin menghemat waktu, biaya, dan karena penelitian ini hanyan untuk memenuhi tugas akhir/Skripsi maka peneliti menggunakan 4 tahap.

Pada tahap pengumpulan data Pengumpulan data ini digunakan untuk memecahkan masalah yang dihadapi peneliti tentang sumber ide dalam merancang/mendesain suatu produk busana pesta malam. Sumber ide yang telah diambil pada mitologi Yunani adalah Dewi Athena dan hal-hal yang berkaitan dengan Dewi Athena. Selain pengumpulan data tentang sumber ide, peneliti juga mengumpulkan data tentang teori desain, busana, busana pesta malam, dan pembuatan pola. Teori-teori ini didapatkan dari buku dan sumber lainnya.

Setelah pengumpulan data tahap selanjutnya adalah tahap perencanaan, dalam tahap ini peneliti membuat enam desain sketsa dam memilih dua desain yang menurutnya sangat sesuai dengan sumber ide dari mitologi kerajaan Yunani.
Setelah memilih dua desain sketsa kmudian membuat detail desain busana dan analisis desain busana.

Tahap pengembangan yang sudah direncanakan. Pada tahap ini peneliti mengadaptasikan penelitian dari penelitian yang dilakukan oleh Puspa Puspita Sarih pada tahun 2016 dengan judul perancangan gaun muslimah dengan bertema etnic colony untuk urban mama dengan teknik aplikasi imbuh. Menunjukan bahwa perancangan busana pesta tidak hanya bisa dengan satu sumber ide. Kaitannya dalam penelitian ini bahwa busana pesta yang dikembangkan merupakan sebuah busana yang pengembangannya sama-sama menggunakan satu atau lebih sumber ide, yang dari sumber tersebut dikaji sehingga menghasilkan sebuah bentuk baru dari busana. Dalam penelitian ini pengembangan bentuk busana perang Dewi athena yang dikombinasikan dengan pengambilan siluet busana dari tiang kuil parthenon untuk mengubah siluet dari busana perang seelumnya agar lebih simple dan praktis. Kemudian mengubah prisai Aigis pada bagian dada menjadi sulam aplikasi bordir brokat yang ditaburkan payet dan mote agar busana tersebut sesuai denga kesempatan busana pesta malam gala. menambahkan warna busana seperti warna kuil, warna emas tembaga untuk memberi kesan kuat sebagai pengganti atribut busana perang Ahena. Bahan busana yang digunakan adalah satin gliter sebagai bahan utama, kain tile, dan kain hero untuk bagian furing. Sedangkan untuk menghias busana digunakan brokat timbul untuk membuat sulaman Aplikasi, payet, mote, permata, kawat dan matras yang sudah dilengkapi gliter untuk membuat aksesoris. Dan bahan pelengkap untuk pembuatan busana seperti benang, bisban, filsofik, dan lain-lain.

Selanjutnya untuk mengetahui kualifikasi produk busana pesta malam gala maka peneliti melakukan uji produk menggunakan instrumen penilaian, uji produk dilakukan oleh dua orang ahli, ahli pertama berasal dari seorang guru jurusan tata busana SMKN 2 Singaraja dan ahli 
kedua seorang praktisi industri busana yang bertempat di Singaraja.

Hasil uji produk pengembangan busana yang terlihat pada tabel 4.2 memperlihatkan hasil uji produk ahli I dengan presentase $91,77 \%$ dan ahli II dengan presentase $87,06 \%$ dengan total kedua ahli yaitu $89,41 \%$ dengan penghitungan tersebut, maka kualifikasi produk pengembangan busana pesta malam dengan sumber ide dari mitologi kerajaan Yunani dikatagorikan Baik.

\section{Hasil Pengembangan Busana Pesta Malam.}

Dari hasil penelitian

pengembangan busana pesta malam dengan sumber ide dari mitologi Kerajaan Yunani, terdapat dua jenis busana pesta malam dimana setiap model busana ada pebedaan. Meskipun sumber ide yang diambil sama yaitu tentang mitilogi Yunani tapi menghasilkan busana yang berbeda antara busana pesta malam I dan busana pesta malam II. Dilihat dari model busana pesta malam I menggunakan draperi pada selendang, bagian badan gaun model camisol, model rok menggunakan model rok span panjang maxi, dan bagian kanan rok terdapat belahan mulai dari pertengahan paha sampai ujung bawah rok. Serta menggunakan furing tutup. Sedangkan busana pesta malam II menggunakan variasi lengan antara cape dan selendang, pada bagian garis leher badan depan dan belakang menggunakan garis leher $\mathrm{V}$, menggunakan tali pada bagian badan belakang, untuk model rok yang digunakan adalah model rok semi mermaid, serta menggunakan furing lepas.

Meskipun busana pesta malam yang dibuat berbeda pada segi model, tetapi busana pesta malam yang ke I dengan yang ke II terdapat persamaannya yaitu menggunakan warna dan bahan utama yang sama. Kemudian sama-sama menggunakan retsleting jepang, dan busana pesta one piece.

Berdasarkan penilaian yang diberikan oleh para ahli isi dan ahli produk pengembangan busana pesta malam dengan sumber ide dari mitologi kerajaan Yunani, maka peneliti dapat melakukan analisis data dengan teknik analisis data deskriptif sebagai berikut.

Tabel 3. Hasil Analisis Data Deskriptif

Hasil Penilaian Oleh Para Ahli isi $\begin{aligned} & \text { Hasil Penilaian Oleh Para Ahli } \\ & \text { Produk }\end{aligned}$

\begin{tabular}{|c|c|}
\hline $\begin{array}{l}\text { 1. Para ahli isi menilai } \\
\text { instrumen pengembangan } \\
\text { busana pesta malam } \\
\text { dengan sumber ide dari } \\
\text { mitologi kerajaan Yunani } \\
\text { dengan hasil valid }\end{array}$ & $\begin{array}{ll}\text { 1. Ahli produk menilai } & \text { busana } \\
\text { pengembangan } & \text { bengan } \\
\text { pesta malam dengan } & \text { sumber ide dari mitologi } \\
\text { kerajaan Yunani } & \text { dengan } \\
\text { kualifikasi produk baik. }\end{array}$ \\
\hline & 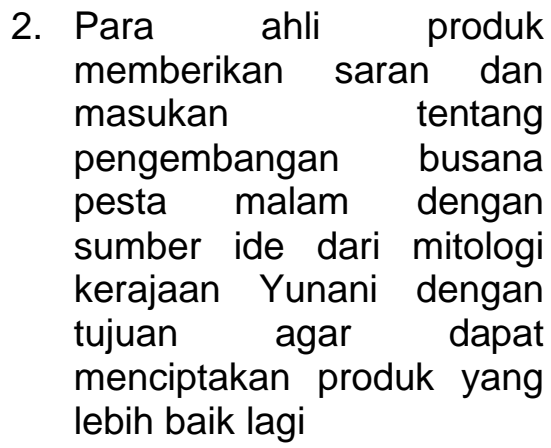 \\
\hline
\end{tabular}

Bedasarkan analisis data deskriptif kualitatif, peneliti dapat simpulkan bahwa isi instrument yang dibuat dapat dikatakan valid dengan derajat validitas sangat 
Jurnal Bosaparis: Pendidikan Kesejahteraan Keluarga

Volume 9, Nomor 3, November 2018

tinggi. Sedangkan produk busana pesta malam dengan sumber ide dari mitologi Kerajaan Yunani terdapat kekurangan menurut ahli produk, teknik jahit peneliti yang masih kurang, peneliti disarankan menggunakan bahan kufner pada bagian badan gaun untuk kesempurnaan gaun. Bahan kufner adalah sejenis kain gula yang digunakan di bagian buruk kain untuk menunjang bahan utama sehingga terkesan kaku dan tidak berkerut saat dipakai. Kerutan pada busana ini dikarenakan bahan utama terlalu licin dan juga terdapat hiasan aplikasi payet sehingga hasilnya sedikit berkerut dan membutuhkan kain kufner. Berdasarkan data yang diperoleh dari hasil validitas uji produk maka kualifikasi produk dapat dikatgorikan Baik.

\section{SIMPULAN DAN SARAN \\ Simpulan}

Berdasarkan hasil penelitian dan pembahasan pada penelitian pengembangan busana pesta malam ini dapat disimpulkan bahwa hasil uji kedua ahli isi dengan nilai 1,00 maka instrumen penilaian pengembangan busana pesta malam dengan sumber ide dari mitologi kerajaan Yunani dapat dikatakan valid dan hasil penilaian ahli produk pengembangan busana pesta malam dengan penskoran uji produk ahli I dengan nilai $91,77 \%$ dan uji produk ahli II dengan nilai 89,06\% maka dapat direratakan dengan nilai $89,41 \%$ dengan hasil kualifikasi baik.

\section{Saran}

Berdasarkan hasil yang diperoleh dari penelitian pengembangan busana pesta ini mendapatkan penilaian yang baik dari para ahli isi dan juga ahli produk. Sehingga penelitian ini bisa dijadikan sebagai salah satu acuan atau contoh dalam penelitian pengembangan busana selanjutnya.

\section{DAFTAR RUJUKAN}

Chodiyah dan Wisri A. Mamdy, 1982, disain busana anak untuk SMK, SMTK, Jakarta: CV Putra Jaya.

Emzir. 2013. Metodologi Penelitian Pendidikan. Depok: PT. Raja Grafindo Persada.
Pedoman Penelitian Universitas Pendidikan Ganesha. 2016. Singaraja : Universitas Pendidikan Ganesha.

Sukmadinata, Nana Syaodih. 2006. Metode Penelitian Pendidikan. Bandung: PT Remaja Rosdakarya.

Soekarno. 2002. Buku Penuntun Membuat Pola Busana Tingkat Dasar. Jakarta: PT Gramedia Pustaka Utama.

Tegeh, I Made \& I Made Kirna. 2010. Metode Penelitian Pengembangan Pendidikan. Buku Ajar (tidak diterbitkan). Singaraja: Universitas Pendidikan Ganesha.

Tegeh, I Made, dkk. 2014. Model penelitian pengembangan. Yogyakarta: Graha ilmu

Widarwati, Sri, dkk. 1996. Desain Busana I. Yogyakarta: IKIP Yogyakarta. 